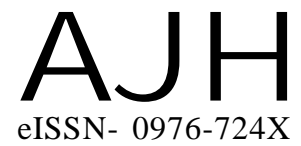

Received : 11.01.2018

Revised : 01.05.2018

Accepted : 15.05.2018

Members of the Research Forum

Associated Authors:

${ }^{1}$ Department of Horticulture, Faculty

of Agriculture, Annamalai

University, Annamalainagar,

Chidambaram (T.N.) India

Email : hortsekar@yahoo.com

Author for correspondence :

K. Sekar

Department of Horticulture, Faculty

of Agriculture, Annamalai

University, Annamalainagar,

Chidambaram (T.N.) India

Email : devanathanramalingam@

gmail.com
THEASIAN JOURNAL OF HORTICULTURE

Volume 13 | Issue 1 | June, 2018 | 1-4

Visit us -www.researchjournal.co.in

DOI : 10.15740/HAS/TAJH/13.1/1-4

\title{
Effect of organic fertigation on yield and quality of bell pepper (Capsicum annuum var. Grossum Sendt.)
}

\section{R. Devanathan ${ }^{1}$ and K. Sekar}

ABSTRACT : Investigation on effect of organic fertigation on growth and yield of bell pepper (Capsicum апnиum var. grossum Sendt.) was carried out at vegetable unit, Department of Horticulture, Faculty of Agriculture, Annamalai University, Annamalai Nagar, Tamil Nadu, during 2016-2017. There were nine treatment combinations including organic manures viz., farm yard manure, vermicompost, bio-stimulants (Humic acid and Sea weed extract) and organic fertigation with Neem cake (two levels viz., 1:20 and 1:40 dilution). Among the nine treatments, the treatment $\mathrm{T}_{7}$ (Humic acid granules @ 5 g plant ${ }^{-1}+$ fertigation with Neem cake 1:20) exhibited the highest yield of $580.18 \mathrm{~g} \mathrm{plant}^{-1}$, and it was followed T (RDF $250: 150: 150 \mathrm{~kg} \mathrm{NPK} \mathrm{ha}^{-1}$ ) with $561.5 \mathrm{~g}$ plant $^{-1}$. However, the lowest yield was recorded under $\mathrm{T}_{8}\left(\mathrm{FYM} @ 125 \mathrm{~g} \mathrm{plant}^{-1}+\right.$ fertigation with Neem cake 1:40) with $319.6 \mathrm{~g} \mathrm{plant}^{-1}$. Among the nine treatments, the per se effect of organic basal supplements derived from the treatment combinations revealed the superiority of humic acid over other organic supplements.

KEY WORDS : Bell pepper, Organic fertigation, FYM, Vermicompost, Sea weed extract, Humic acid

HOW TO CITE THIS ARTICLE : Devanathan, R. and Sekar, K. (2018). Effect of organic fertigation on yield and quality of bell pepper (Capsicum annuum var. Grossum Sendt.). Asian J. Hort., 13(1) : 1-4, DOI : 10.15740/HAS/TAJH/13.1/1-4. 